\title{
ASPECTOS LEGALES DE LOS TRANSPLANTES
}

\section{DE ÓRGANOS}

La reciente presentación en la Universidad Católica del Perú y en la Universidad Nacional de Trujillo de dos tesis que se relacionan con el trasplante de órganos, justifican el presente artículo que trata del aspecto jurídico de dicho tema, que es de gran importancia sobre todo por su actualidad y por sus posibles repercusiones en la colectividad.

La primera, es obra del ex alumno de la Facultad de Derecho de la U.C., señor Juan A. Danós Ordóñez, titulada "Aspectos Jurídicos de los Trasplantes de Organos y nuevas figuras penales sancionadas por el Código Sanitario del Perú (D.L. No. 27505)" que nos ha servido mucho en la confección de estas líneas, por lo cual le agradecemos a dicho alumno y discipulo nuestro; $y$ la segunda sustentada por el abogado, Dr. Manuel Cisneros Durandel, ha sido presentada bajo el epígrafe "Ensayos sobre algunas cuestiones jurídicas suscitadas por los Trasplantes" y de la que desgraciadamente no hemos podido obtener un ejemplar.

Es conveniente advertir que el trasplante de órganos, sobre todo, el corazón y la definición de la muerte están estrechamente vinculados y fueron am. pliamente tratados a sugerencia de las Academias, Nacional de Medicina y Peruana de Cirugra, en un Simposium reunido en Lima, diciembre de 1970, bajo el título de "Muerte y Trasplante de Organos", en el que intervinieron además de los médicos integrantes de dichas instituciones académicas, distinguidos jurisconsultos como los doctores José León Barandiarán, Luis del Valle Randich y Luis Angulo Bezada; estos dos últimos sensiblemente desaparecidos. Posteriormente, en el XVIII Congreso Peruano de Cirugra y en el XIX Congreso Mundial de Cirugfa, realizado en esta Capital en marzo del presente año, tuvimos oportunidad de tratar de semejantes temas. No es posible dejar de mencionar, que es fundamental en relación con el aspecto jurídico de los trasplantes de órganos, conocer el Código Sanitario del Perú, obra del destacado jurista que fuera Asesor Jurídico del Ministerio de Salud, Dr. Luis Angulo Bezada, a cuyos meritorios esfuerzos $e$ incansable labor se debe la confección de dicho cuerpo de doctrina, su aprobación por el supremo Gobierno y la dación de la ley respectiva. Un deber elemental de justicia, hace que exaltemos los singulares méritos de tan distinguido profesional a quien en vida no se le reconocieron los valiosos quilates jurídicos de su obra de positivo beneficio para la nacionalidad.

La práctica de la incorporación de tejidos u órganos en el organismo humano no es muy reciente, pues, hace años se utiliza la piel, la sangre y posteriormente la córnea en ciertas circunstancias. Es desde hace pocos años que se ha generalizado dicha intervención quirúrgica, siendo utilizados órganos de intensa fisiología, como el corazón y los riñones. A partir de 1967 se ha dado gran impulso a la práctica de los trasplantes en la especie humana y pese a los múltiples tropiezos, el auge continúa, abriéndose nuevas posibilidades conforme avanza la ciencia de la Inmunología, elemento crucial en la práctica de dichos trasplantes.

Elocuente demostración de que el desarrollo científico permitirá hacer más factibles los procedimientos de trasplantes de órganos se advierte en relación con la transfusión sanguínea, que, iniciada hace muchos años con desastrosas consecuencias en sus comienzos, sólo pudo constituir una práctica de terapia diaria, cuando a principios del presente siglo el desarrollo de la Inmunología, permitió descubrir con los grupos sanguíneos los procedimientos de compatibilidad de la sangre.

Es frecuente dividir el capítulo de los trasplantes en dos grandes sectores: el primero a realizarse, con órganos o tejidos entre seres vivos y el segundo con los provenientes de cadáveres para su utilización 
por individuos dotados de vida. Mantendremos dicha división con ciertas salvedades, pues si bien en el trasplante cardiaco, la condición sine-quanon es que el corazón por trasplantar provenga de un cadáver, ya que de otro modo la extracción en el vivo constituiría un homicidio, que podría llegar a calificado; en el trasplante renal, el órgano por extraerse puede provenir indistintamente de un ser vivo o un finado, si bien esta última posibilidad, exige tantos requisitos que alguna vez son imposibles de satisfacer.

En cuanto a la primera contingencia: trasplante de órganos entre seres vivos, el Código Sanitario en su sección IV, art. 43 dice: "La donación de órganos, tejidos o partes del organismo entre vivos es posible siempre que quede acreditado por la opinión de dos médicos, por lo menos, en consulta, que la falta del órgano, tejido o parte del organismo no altere la salud 0 el tiempo de vida del donante $y$ no tenga por efecto, causar una pérdida grave $y$ definitiva en la integridad del cuerpo humano. La donación se efectuará sin ninguna condición".

Los requisitos están claramente consignados en el sentido de que no se trate de un órgano vital e indispensable para la vida humana, que medie consentimiento entre dador y receptor y que la extracción del órgano, no afecte ni la salud, ni la vida del dador.

El consentimiento, es una de las condiciones del trasplante de acuerdo con lo estipulado en el art. $13 \mathrm{del}$ Reglamento, $y$ es entre el disponente $y$ el receptor. Se trata de una verdadera donación entre vivos que además del consentimiento y la verificación de su capacidad legal, exige la confirmación del estado de salud, realizada por los médicos designados por el propio disponente, de acuerdo con el art. 9o. del mismo Reglamento,en la que los profesionales examinadores aseguren la innocuidad de la extracción con la advertencia de que "no es posible garantizar con absoluta certeza, que en alguna contingencia ulterior, en el curso de la vida, la falta de órgano o tejido pueda llegar a significar un factor de déficit funcional".

El consentimiento, es uno de los requisitos para el trasplante entre seres vivos y debe ser en forma escrita, como documento que hace indudable voluntad de ambos: dador y receptor, y que para mayor garantía debe ser refrendado por el Director del no. socomio en que se va a realizar el trasplante.

El consentimiento es la expresión deliberada, consciente $y$ libre de la voluntad respecto a un acto externo, deseado y espontáneo. Para el dador es la expresión de su deseo de ceder un órgáno de su cuerpo, aún con los riesgos inherentes y para el receptor es la aceptación del mismo y de su acuerdo para que se verifique el trasplante. Es en sintesis, un hecho jurídico basado en la voluntad humana o sea el consentimiento que tipifica una verdadera donación, en la que según el Código Civil, puede existir dos situaciones:

a) Cuando la donación del órgano o tejido es cedida sin remuneración, $y, b)$ cuando es mediante la misma, como condición indispensable.

En el primer caso, es una donación pura y simple, según el art. 1146 del Código Civil, que se refiere a la transferencia de cosa o cosas, con la salvedad de que los órganos y demás partes del cuerpo humano son considerados Rex Extra Commercium, es decir sin representación patrimonial y fuera del comercio de los hombres. Trátase de una verdadera donación, con criterio jurídico o legal de acuerdo con nuestra Legislación.

En el segundo, o sea cuando media remuneración, en el Código Sanitario existe una verdadera antinomia, pues en tanto que el art. 43 dice que la donación de órganos o tejidos para el trasplante "debe hacerse sin ninguna condición", en el siguiente art. 44 se señala que la disposición "de tejidos restituibles puede ser remunerada". La remuneración es el pago de servicios prestados, verdadero reembol. so por la donación de un órgano.

En Derecho, es unánime el concepto de que el cuerpo humano no es una mercancía, susceptible de comercialización, sobre todo porque no existe un derecho de propiedad sobre el mismo o alguna de sus partes, ya que niega al hombre la facultad de disponer de ellos, y con mayor razón, de celebrar negocios jurídicos sobre los mismos.

Hoy existe en la normativa de los trasplantes la posibilidad de una contraprestación en la cesión de órganos restituibles para su extracció e implantación en otra persona, es decir se ha abierto la posibilidad de establecer una verdadera compra-venta de un organo o un tejido, como una incipiente acción contraria a la tradición. Aunque acuse ello una tendencia avanzada puede aceptarse como la aceptación de una retribución pecuniaria, por quien está facultado para permitir el empleo de un órgano o un tejido de gran utilidad $y$ aún de urgente necesidad vital, en una sociedad organizada, sobre la base del interés y del lucro $y$ en la cual no se han desarrollado, sino en forma incipiente los sentimientos de solidaridad humana. De acuerdo con la realidad dicho tipo de 
transacciones, que comprende al cuerpo humano en su integridad y sus órganos en particular, han cobrado un valor económico tangible.

Pese a la campaña contraria a la retribución económica, el Código Sanitario ha sido realista y encontramos acertada la posibilidad de la remuneración.

A pesar de los muchos riesgos de la comercialización desenfrenada, mayor en nuestro medio -por el bajo índice cultural- donde aún persisten muchos prejuicios e inhibiciones de orden moral, la tendencia mundial es de tolerancia, como lo demuestra la ley francesa del 21 de julio de 1952, que acepta la venta de sangre humana.

Respecto a la persona que por ceder sus tejidos u órganos hace una donación, sin remuneración alguna, cede a sus sentimientos altruistas como evidente demostración de solidaridad ante el dolor. En cuanto a sus derechos, el principal es la facultad para revocar su decisión tal como se consigna en el art. 45 del Código Sanitario. El otro consiste en que los médicos deben garantizar la falta del órgano, tejido o parte del organismo, al ser cedido no alterará la salud o tiempo de vida del donante $y$ tampoco causará una pérdida grave y definitiva en la integridad del cuerpo humano. Así lo consignan los artículos 43 del Código y 9o. del Reglamento.

Serŕa conveniente la incorporación a nuestra Le-ł gislación de la obligatoriedad de adquirir una póliza de vida en beneficio del dador, como compensación de la actitud de desinteresado desprendimiento en favor del receptor.

Según el art. 4o. del Reglamento, los menores e incapaces están prohibidos de actuar como donantes, pudiendo sí ser receptores con el consentimiento previo de sus padres o tutores.

En el aspecto médico, dos condiciones son indispensables para el dador: el examen médico, ya referido anteriormente $\mathrm{y}$ las pruebas biológicas de determinación de grupos sanguíneos y factores $\mathrm{RH}$ y sobre todo, la histocompatibilidad celular, también denominada linfocitaria.

En cuanto a los receptores, es conveniente informarles y a sus familiares más próximos, de la necesidad de que otorguen su consentimiento, de los detalles y resultados de los exámenes clínicos, de las pruebas serológicas, de histocompatibilidad, etc. $y$ de los posibles riesgos posteriores al trasplante. De acuerdo con el art. 8o. del Reglamento ello es potestativo del Director del establecimiento de salud en que ha de realizarse el trasplante.

Cuando se trata de trasplantes de tejidos, órganos o partes del organismo provenientes de cadáveres, las disposiciones legales son las que a continuación se expresan. Los considerandos de la Reglamentación señalan lo siguiente: Después de la muerte, puédese disponer de todo o parte de un cuerpo siempre que su poseedor natural en vida no disponga lo contrario; que toda persona que padezca de una lesión irreductible tiene derecho al uso para trasplante, del órgano o tejido aprovechable del muerto; que los principios de Deontología Humana, tienen importancia fundamental en todos los momentos que conforman el proceso de un injerto o trasplante, cualquiera que sea la forma que adopte su ejecución. El art. 2 del mismo, inciso E, precisa que el trasplante de órganos vitales requiere la muerte del sujeto que los poseía en vida. El art. 5 inciso a, dice: Dicha muerte será certificada por médicos distintos de los que formen el equipo que realice el trasplante, científicamente comprobado; b) que el receptor padezca de lesión irreductible en el órgano por reemplazarse. El art. 6o., afirma que producida la muerte clínica, se podrá usar procedimientos para la conservación de la vida independiente de los órganos para ser trasplantados. El art. 7o. dice, que el receptor deberá ser informado por el director del establecimiento de salud en que se encuentre, de la procedencia del tejido u órgano por trasplantarse, así como de las medidas de seguridad adoptadas para el buen éxito dela operación. El art. 8o., obliga al mismo funcionario, aś como al patólogo e inmunólogo, que forman el equipo técnico del trasplante, bajo responsabilidad de informar al receptor $y$ a sus familiares, o a quienes los representen, si los hay, sobre la calidad concluyente o no, de las pruebas para determinar la compatibilidad tisular entre los órganos y tejidos del dador y receptor $y$ sobre las posibles reacciones inmunológicas $y$ riesgos.

El art. 24 exige que la certificación de la muerte clínica, debe ser suscrita por un grupo de médicos, no menos de tres en equipo, de los que uno será cardiólogo y otro neurólogo, cuyos acuerdos serán unánimes, no pudiendo ninguno de ellos formar parte del grupo que realice el trasplante. El art. 26, señala que para la utilización de un órgano aprovechable de un finado, se requiere: a) consentimiento del sujeto antes de morir; b) del familiar más próximo, a falta del requisito anterior, y c) autorización del director del establecimiento de salud, en ausen- 
cia de los familiares, dentro de las 24 horas del fallecimiento.

El art. 27 exige que el consentimiento, a que se refieren los incisos a) y b) del artículo anterior debe constar por documento que pruebe, en forma indudable, la voluntad manifestada, siendo prohibido el procedimiento verbal. Finalmente, el art. 28 se refiere a que el trasplante de un organo vital o indispensable para la vida humana, debe ser igualmente autorizado por el sujeto receptor o quien lo represente por documento.

El código Sanitario, en su sección VI, específicamente denominado la Muerte, se ocupa de ésta, en once artículos, de los que extractamos el contenido de los principales, para no dilatar aún más esta exposición. Art. 36, la Muerte se produce por la cesación de los grandes sistemas funcionales, consi. derando que el fin de la vida, productora de consecuencias jurídicas, no corresponde a la verdad biológica. Art. 37, la declaración del fallecimiento, es de absoluta responsabilidad del médico que la certifica. Art. 41, para los efectos del trasplante o injerto de un órgano vital o indispensable para la vida humana, se considera muerte el paro irreversible, de la función cerebral, confirmada por el electroencefalograma u otro método científico más moderno, empleado en el momento de la declaración. Art. 42. El tiempo para la utilización del órgano aprovechable de un muerto, será determinado por el médico después de la declaración del fallecimiento y no antes, dado que el paro de la actividad cardiáca o respiratoria, caracteriza la llegada de la muerte, pero no son la muerte misma.

Finalmente en el libro tercero del Código, titulado de los Delitos $y$ de las Sanciones, sección primera, Delitos contra la salud. art. 85 , se lee: Constituye delito contra la salud: inciso $\overline{\mathrm{N}}$ : "La utilización de un órgano vital, para injerto o trasplante, antes del fallecimiento del dador".

Del estudio de los aspectos legales de los trasplantes contenidos en el Código Sanitario $y$ en el Reglamento general de injertos, trasplantes de órganos, tejidos y partes del organismo; se advierte que han sido contemplados en toda su amplitud, confiriéndoseles la importancia que en sf llevan. Han sido estudiados los aspectos médicos y jurídicos, revelando el claro criterio del autor, al que no se le ha rendido el justiciero homenaje por su labor, reveladora de su profundo conocimiento jurldico no exenta de implicancias médicas.

Una demostración del amplio conocimiento del mismo, enemigo de rigorismos de cualquier índole $y$ a tono con los adelantos de la Ciencia, es el capitulo de mayor interés para los médicos, el relacionado con la muerte. En el art. 41 se considera como tal el paro irreversible de la función cerebral, confirmado por el electroencefalograma $u$ otro medio cient fíco más moderno, lo que permite la posibilidad de aceptar las innovaciones que nuevos descubrimientos puedan determinar en relación con el diagnóstico del deceso.

Efectivamente, ante los clásicos signos de la muerte real: los positivos y negativos, anacrónicos en el momento actual, han surgido nuevos métodos $y$ conceptos de diagnóstico precoz, que es lo que interesa para la utilización de los órganos en los trasplantes, antes que el proceso natural haga inútiles los mismos, por la iniciación de la descomposición cadavérica. Hace más de veinte años, en Italia la ley declaró que la realidad de la muerte debe hacerse según el criterio de la semiótica médico legal, usando el método electro-cardio-tanato diagnóstico. En la actualidad se acepta que la muerte surge con la interrupción - sin ninguna posibilidad de recobrarse- de la actividad cerebral. - Ella se diagnostica -además de los signos clínicos sobre todo en relación con los aparatos circulatorio y respiratorio -por medio del electroencefalograma, que aunque sus trazados no siempre son convincentes, el conflicto surge en relación con el tiempo que debe durar el silencio eléctrico o sea la persistencia del electroencefalograma plano.

Desde 1966, surge un criterio más efectivo ante la rivalidad de los datos electroencefalográficos $y$ es la detención de la circulación cerebral que atestigua la muerte cierta. Por la angiografía carotidea bilateral $y$ vértebrobasilar se puede determinar la ausencia de sangre en el cerebro, la que observada durante quince minutos, es definitiva en el sentido del daño, cierto e irreversible, identificado con la muerte.

El problema del diagnóstico precoz de la muerte, como factor fundamental para la extracción del corazón y riñón, antes que elios se deterioren, es de tal complejidad que todas las instituciones docentes y académicas mundiales y la O.M.S. se han ocupado detenidamente, del asunto sin resultados uniformes.

En sintesis:

Definir la muerte es un problema de indole biológico; comprobarla lo es esencialmente médico legal y de hecho,la solución de este último lleva consigo consecuencias jurf́dicas.

Lima, febrero de 1974. 